(C) Derek J. Mancini-Lander, 2018

\title{
Subversive Skylines: Local History and the Rise of the Sayyids in Mongol Yazd ${ }^{1}$ by Derek J. Mancini-Lander
}

From out of the arcane abode of the wheel of fortune, The juggler began to juggle and a strange affair came about.

-Muhammad Mufìd Mustawfì Bāfqī

Jāmi' $-i$ Mufìd̄

The strange affair that the author of the above passage was about to relate was a rather coarse tale of revenge and retribution in the provincial city of Yazd during the period of Ilkhanid rule in the early eighth century $\mathrm{AH} /$ fourteenth century $\mathrm{CE}$. The episode begins with a row between two locals: Yūsufshāh, an Atābeg ruler from the old Saljukid military aristocracy, whose esteemed ancestors had ruled Yazd for generations; the other was an eminent imāmzāadah, or Husaynī sayyid, Ruknuddīn Muhammad, who had inherited the office of naqīb of the city. The short of it was that the sayyid had constructed a new madrasah complex, known as the Ruknīyah, directly beside the Atābeg's family madrasah, called Madrasah-i Maḥmūd Shāhī. The two men started competing for turf, reputation, and the distinction of erecting the bigger minaret. But in the accounts of this story, which had begun so crudely with an episode of violent confrontation in Yazd, this local conflict proceeds to worm its way outside the city walls and to insinuate itself into affairs in other places across the imperial realm. Once animated in this way, the tale unfolds in a sublime register, turning a local rivalry into a moralizing story about the fall of tyranny's fortunes and the rise of divinely ordained justice, manifested in the sacred bodies of the Prophet's descendants. At the same time, the narrative reveals yet another story of the re-ordering of power and authority within the Ilkhanid domains. This larger narrative that this study sets out to untangle is the story of the rise of the sādāt (plural of sayyid) and their madrasah-tomb

\footnotetext{
${ }^{1}$ The author wishes to extend his deep gratitude to the anonymous referees whose insightful comments and keen criticisms proved invaluable.
} 
complexes. This is the history, not only of the florescence of sayyids as notables in provincial cities, but also of their emergence as key agents of empire, whose sanctity allowed them to wield power and authority both in the provinces and at the imperial court. The sayyids of urban centers, especially of Yazd, would continue to exert their influence and authority at the political center until well into the Safavid period.

The emergence of the sādāt as local magnates was already well underway between the third/ninth and fourth/eleventh centuries. ${ }^{2}$ However, as Jean Aubin observed, the status and influence of the Prophet's descendants in imperial affairs increased markedly during the Mongol dispensation, when the Îlkhāns relied on the cultural mediation of religious elites and other urban notables. These urban, generally Tājīk elites brokered the Mongols' conversion to Islam and adaptation to Persianate culture. ${ }^{3}$ More recent studies have built on Aubin's work, finding that as the sādāt redoubled their local authority under Ilkhanid rule, they also began to move beyond the boundaries of their local jurisdictions to influence affairs at the imperial center more directly. Judith Pfeiffer has demonstrated that the Îlkhāns actively promoted the status of the sādāt within the realm and patronised their institutions across the empire. ${ }^{4}$ The sayyids' local and transregional ascendancy is evident from their increasingly impressive building programs in their home cities and in other towns throughout the realm.

\footnotetext{
${ }^{2}$ On the sādāt in the pre-Mongol period see the myriad works of Kazuo Morimoto, especially his edited volume: Sayyids and Sharifs in Muslim Societies: The Living Links to the Prophet (New York: Routledge, 2012). Also see Teresa Bernheimer, The 'Alids: The First Family of Islam, 750-1200 (Edinburgh: University of Edinburgh Press, 2013) and Scarcia Amoretti, Biancamaria and L. Bottini eds., The Role of the Sādāt/Ashrāfin in Muslim History and Civilization: Proceedings of the International Conference Rome, 2-4 March, 1998: Oriente Moderno 18(79)/2, 1999. 3 Jean Aubin, "Emirs mongols et viziers persans dans les remous de 1'acculturation," Studia Iranica, Cahier 15, Paris, 1995. Also see his Deux sayyids de Bam au XVe siècle; contribution à l'histoire de l'Iran timouride, Abhandlungen der Geistes- Und Sozialwissenschaftlichen Klasse 7 (Wiesbaden: Verlag der Akademie der Wissenschaften und der Literatur, 1956).

${ }^{4}$ Judith Pfeiffer, "Confessional Ambiguity vs. Confessional Polarization: Politics and the Negotiation of Religious Boundaries in the Īlkhānate," in Politics, Patronage, and the Transmission of Knowledge in 13 $3^{\text {th }}-15^{\text {th }}$ Century Tabriz, ed. Judith Pfeiffer (Leiden: Brill, 2014), 129-168.
} 
Examination of Persian accounts of the contest over the Ruknīyah madrasah, set to paper for the first time more than a century after the events in question, reveals that the changes that enabled the sayyids' rise during the Mongol period ultimately paved the way for elites without sayyid lineages to become influential agents of empire, too. It is well known that by the Timurid and early Safavid periods, the sayyids and local patricians who had allied themselves with sayyids had become instrumental in the articulation of imperial rule, achieving influential positions at court and often composing consequential works of imperial history. This was especially true of Yazdīs, including important Yazdī notables from sayyid, but especially from non-sayyid lineages, such as Sharafuddīn 'Alī Yazdī (d. 858/1454), the great intellectual and historian of the Timurids; several Ni 'matullāhīs such as the Vazīr and Vakīl of Shāh Isma '̄ill, 'Abd al-Bāqī (d. 920/1514); and Jalāluddīn Yazd̄̄, Shāh 'Abbās's chief astrologer and court historian. This study asserts that the political involvement of Yazd's sayyids and later of nonsayyid elites in imperial affairs beyond the local level must be understood in terms of long-term shifts in the perceived nature of the sayyids' sacredness. After the Ilkhanid period, the sayyids, whose religious and political authority had primarily emanated from sacred lineage, began to accrue mantic and thaumaturgic attributes of sanctity generally characteristic of Sufi saints. It is no coincidence that these were changes that immediately followed the burgeoning of Sufi religiosity during the Mongol period, namely, the emergence of shrines as key centers of religious devotion and urban economies, and the resultant blossoming of symbiotic relationships between sovereigns and Sufi saints, which bestowed kings with an aura of sacredness and Sufis with royal patronage and a share of temporal power. To these one must add the increasing determination among both Sufis and sovereigns to demonstrate 'Alid pedigree, albeit sometimes with the assistance of esoteric explanations. ${ }^{5}$ The famous ascendancy of the Safavid monarchs in

\footnotetext{
${ }^{5}$ See, for example, Azfar Moin's discussion of the mysterious 'Alid lineage attributed to Tīmūr on his sarcophagus,
} 
907/1501-2 only represents the crystallization of this process of convergence between Sufis, sayyids, and sovereigns that had been underway since Ilkhanid times. The Safavids' legitimacy rested on a combination of Sufi lineage, descent from the seventh Imām, dramatic spectacles of charismatic authority, and awesome military conquest. Later accounts of the unfolding of events in Mongol Yazd show that as sayyids' thaumaturgic displays of authority began to appear more frequently alongside invocations of Ḥusayn̄̄ ancestry, charismatic signs of divine endorsement began to temper the exclusive purchase of sacred lineage. Elites who could not claim descent from the Prophet but who could demonstrate even a tenuous association with the sayyids or with their new styles of charismatic authority could claim some share of their sacred patrimony, albeit in diluted form. This patrimony could be utilized as a means of exhibiting authority in competition for administrative roles or for influence in imperial affairs more broadly.

\section{Sources}

The sudden appearance of Yazd's sayyids in the arena of imperial administration during the Ilkhanid period, which stands at the center of the events scrutinized here, must be examined using a combination of Ilkhanid-era documentary and narrative sources, particularly the famous general histories of Rashīduddīn Fażlullāh, Vașșāf, Mustawfì Qazvīnī, Qāshānī, and

Shabānkārah' '1. ${ }^{6}$ However, the court-centered perspectives of these works are complicated when

which explains that 'Alī had impregnated Tīmūr's ancestor, the ancient Mongol queen Alan Goa, in the form of a ray of light. Azfar Moin, The Millennial Sovereign: Sacred Kingship and Sainthood in Islam (New York: Columbia University Press, 2012), 37-39.

${ }^{6}$ Rashīduddīn Fażlullāh Hamadānī, Jāmi 'i Tavārīkh, ed. Bahman Karīmī (Tehran: Iqbāl va Marvī, 1988) [hereafter JT]. 'Abdullāh Vașșāf, Kitāb-i Mustațāb-i Vașṣāf al-Hażrat [Tārīkh-i Vașṣāf], ed. Muhammad Mahdī al-Iṣfahān̄̄ (Bombay, 1269/1853) [hereafter TV]. This study uses two variant editions of Mustawfì Qazvīnī: Hamdullāh Mustawfī Qazvīnī, Tārīkh-i Guzīdah, vol. 1, ed. E.G. Browne (London: Dār al-Sultānīyah-i London, 1910) [hereafter TG-Browne]. Navā'̄'s's edition, published by Amīr Kab̄ir, 1960 is better [hereafter TG-Navā'î]. Abu al-Qāsim 'Abdullāh al-Qāshān̄i, Tārīkh-i Uljāytū, ed. M. Hambalī (Tehran: B.T.N.K, 1969) [hereafter TU]; Muḥammad 'Alī Shabānkārah' '̄, Majma 'al-Ansāb, ed. Mīr Hāshim Muḥaddiṣ (Tehran: Mu’asasah-i Intishārāt-i Amīr-i Kabīr, 1984) [hereafter $M A]$. 
read alongside three local histories of Yazd, composed between the mid-fifteenth and midseventeenth centuries CE. Although these Yazdī works were written later, during the Timurid, Turkoman, and Safavid periods, their chapters on the Mongol era help to clarify a Yazdī perspective on the Ilkhanid processes of acculturation, as they played out on the ground in a provincial center of the realm. ${ }^{7}$ In fact, the authors of these local histories characterize the peculiar rise of Yazd's sayyids during the Ilkhanid dispensation as a turning point in their history and present the strange affair surrounding the Rukniyah's construction as the origin of their current order. Also, the aforementioned long-term shifts in the nature of the sayyids' sanctity and the story of the diffusion of their charismatic patrimony among non-sayyid notables, which occurred after the Mongol period, can be discerned in these late local histories of Yazd. A close historiographical analysis of these Yazdī historians' artful accounts of this period of initial encounter between local elites and Mongol agents reveals the changing ways in which Yazdī writers of later eras made sense of these earlier transformations vis-à-vis contemporary events and deployed them in new ways to negotiate their own places in rapidly evolving and competitive imperial systems.

Although varied in length and content, each of these three local histories of Yazd rehearses the history of the city from its origins in the ancient past to the author's present time, allotting much space to the events in Yazd during the Ilkhanid era. The first is Ja far ibn Muhammad Ja farī’s Tārīkh-i Yazd (hereafter TY), composed in the mid-fifteenth century and dedicated to a vizier in the local Timurid administration from a prominent local family,

\footnotetext{
${ }^{7}$ See Ann K. Lambton, "Persian local histories," in Yâdnâma in memoria di Alessandro Bausani, eds. B.S. Amoretti and Lucia Rostagno (Rome: Bardi Editore, 1991), 227-238; Isabel Miller, "Local History in Ninth/Fifteenth Century Yazd: the Tarikh-i Jadid-i Yazd," Iran: Journal of the British Institute of Persian Studies 27, 1989, 75-79.
} 
Żiyā' uddīn Ma'sūd. ${ }^{8}$ The author was a sayyid who worked in the vizierate of the Timurid governor of Yazd, Amīr Chāqmāq; he was a panegyrist of the governor and, in addition to the Tārīkh-i Yazd, composed two versions of a universal history, Tārīkh-i Kabīr, and Tārīkh-i Wāsit, the latter of which he presented to the Timurid ruler, Shāhrukh, in 820/1417-18. ${ }^{9}$ The second work is Aḥmad Kātib's Tārīkh-i Jadīd-i Yazd (hereafter TJY), composed no later than 872/146768. ${ }^{10}$ Little is known about Aḥmad Kātib save his statement in his preface that he "has always girded the loins of his soul in service to the sādāt and 'ulamā' ... [and] has been present in the assemblies of the elite men of religion and government."11 If he was not a sayyid himself, the author certainly counted himself a devotee of the Prophet's house, and his Persian style corroborates his claim to have travelled in elite circles of administration. Most likely he served in the dīvān under both the Timurid and Qarā Qūyunlū empires, and he reserved high, dedicatory praise in his book for Jahānshāh Qarā Qūyunlū. ${ }^{12}$ The last work, quoted above, is Muhammad Mufĩd's Jāmi 'i Mufìd̄ (hereafter JM), completed in 1090/1679-80. ${ }^{13}$ Although Mufĩd dedicated the work to the reigning Safavid monarch, Shāh Sulaymān (r. 1077-1105/1666-1694), he wrote it while living in exile in India. Before his emigration, Mufĩd had been a mustawfî in Yazd's vizierate, serving as the deputy (nà ib) of the Safavid vizier of Yazd, Allāh Qulī Beg, nephew of

\footnotetext{
${ }^{8}$ Ja far ibn Muḥammad Ja ‘arī, Tārīkh-i Yazd, ed. Īraj Afshār (Tehran: B.T.N.K., 1960), 6. On Żiyā’uddīn and his more illustrious father, 'Imāduddīn, see discussion in Beatrice Forbes Manz, Power, Politics and Religion in Timurid Iran (Cambridge: Cambridge University Press, 2007), 148-9.

${ }^{9} \mathrm{Ja}$ 'farī mentions the posts in Tārīkh-i Kabīr. See discussion in the editor's commentary in TY, 163. Although Ja farī's pedigree is not known, his membership among the sādāt is confirmed by the next historian of Yazd, Ahmad ibn Ḥusayn ibn 'Alī Kātib, in his Tārīkh-i Jadìd-i Yazd, ed. İraj Afshār (Tehran: Amīr Kabīr, 1978), 5-6. A later historian, of the Safavid era, Aḥmad Ghaffārī also calls Ja farī a sayyid in his Tārīkh-i Nigāristān, Bombay, 1859, 5, composed in 1552. Tärīkh-i Wāsit is not extent, but is mentioned as a source in ibid.

${ }^{10}$ As cited in footnote 9.

${ }^{11} T J Y, 4$.

${ }^{12}$ Praise for Jahānshāh is located in $T J Y, 11$. Manz conjectures that earlier he served under the Timurid Prince, Bāysunghur. Manz, Power, 53.

${ }^{13}$ Muhammad Mufīd Bāfqī̄, Jāmi '-i Mufìd̄̄, ed. Īraj Afshār, 3 vols. (Tehran: Asāṭīr, 2007).
} 
the more well-known Amīr Kalb 'Alī Khān. ${ }^{14}$ Upon the vizier's sudden death at the end of 1079/1669, Mufīd took on the office of Nāzirir of the religious endowments (nazāarat-i awqāf), wherein he assumed supervision of "the holy sites (muqaddasāt), illuminated tombs (mazārāt-i munavvarāt) and blessed graves (buq $\bar{a}^{\prime}-i$ khayrāt)," as well as oversight of the sādāt and mustawfìs of the religious endowments. ${ }^{15}$ Mufìd appears not to have been a sayyid himself, but, like each of his predecessors, promoted himself as a devotee of the sādāt and allocated a massive portion of his $J M$ to biographies of men with Husaynī lineages in Yazd. Each of these three authors' livelihoods as functionaries of the local administration and the empire at large depended on the solvency of the endowments supporting the region's sacred sites, particularly those sites associated with the descendants of the Imāms and other saints. The success of these sites relied not only on the financial viability of their endowments, but also on their ability to attract pilgrims. This, in turn, required that the stories of the saintly figures entombed there continued to circulate and to excite the devotional sensibilities of visitors. Thus, in the religious economy of cities like Yazd, writing the history of the sayyids and the local families associated with them, served as a key, sacred component of administration, alongside more mundane duties.

To this trio of sources, one should add another handful: The first is the fourteenth-century waqfiyah for the compendium of all the endowments made by Ruknuddīn Muhammad and his son, Shamsuddīn Muhammad, in Yazd and elsewhere, collected under the title Jāmi 'al-Khayrāt (hereafter $J K) .{ }^{16}$ The second is Mu'īnuddīn Yazdī’s Mavāhib-i Ilāhī (hereafter $\left.M I\right) .{ }^{17}$ This

\footnotetext{
${ }^{14} J M, 3: 657-7$. Mufīd explains that Allāh Qul̄̄ had lived in Yazd for forty years, probably since his uncle, Kalb 'Alī had been given the city as a tuyūl under Shāh 'Abbās II (3:213).

${ }^{15}$ Mufid includes the royal order, dated $1080 \mathrm{AH}$, installing him in that post, which had previously been held by the vizier, himself. $J M, 3: 759-60$.

${ }^{16}$ Ruknuddīn Muḥammad Husaynī Yazd̄̄, Jāmi ‘ al-Khayrāt, eds. Muhammad Taqī Dānish-pazhūh and Īraj Afshār (Tehran: Farhang-i Īrān Zamīn, 1962). The Ruknīyah's vaqf is reproduced in: Afshār, Yādgār'hāa-yi Yazd, 2:391-4.

${ }^{17}$ Despite the existence of Nafīsī's critical edition of $M I$, volume 1, the diverse manuscript tradition requires careful comparison (e.g., footnote 70). Manuscripts employed in this study: British Library Add 7632 (fifteenth century copy); British Library Add 19807 (dated 1042/1633). Istanbul Manuscripts: Fatih 4227 (808/1406, copied in Yazd);
} 
dynastic history of the Muzaffarids was completed relatively close to the events in question, in 767/1365-6. It is not a local history of Yazd per se; it recounts the history of the Muzaffarid dynasty from its origins under the İlkhāns until the apogee of Shāh Shujā' 's reign (r. 759786/1358-1384). However, because its author was a leading Yazdī jurist and teacher, much of his narrative on the early Muẓaffarids and their entanglements with the İlkhāns revolves around the affairs of his home region, where the Muzaffarids rose to power. ${ }^{18}$ Another work, Tārīkh-i $\bar{A} l-i$ Muzaffar (hereafter TAM), completed during the Timurid period, in 823/1420 by Mạ̣mūd Kutubī, comprises a reworking of Mu 'īnuddīn Yazdī's prolix history, which the author composed as a continuation of Mustawfî's Tārīkh-i Guzīdah. Some manuscripts of Mustawfî’s work contain Kutubī’s additions. ${ }^{19}$

\section{Yazd, the Īlkhāns, and Imperial Intermediaries}

Even before the tumult that triggered the strange affairs in Yazd which opened this study, the city had developed a unique relationship with the Ilkhanid court, an arrangement that resulted largely from the machinations of the famous and powerful Rashīduddīn Fażlullāh Hamadān̄̄, the Grand Vizier and physician who introduced important reforms during Ghāzān Khān’s reign and composed numerous works, including the voluminous Jāmi ‘ al-Tavārīkh. ${ }^{20}$ The Yazdī historians

\footnotetext{
Aya Sofia 3088 (dated 910/1504 copied in Constantinople); Aya Sofia 3087 (dated 900/1494); Esad Efendi 2082 (probably tenth/sixteenth century); Fatih 4226 (893/1488). Published edition: Mu īn al -Dīn Yazdī, Mavāhib-i Ilāhī, ed. Sa '̄ìd Nafīsī (Kitābkhānah va Chāpkhānah-i Iqbāl, 1326) (hereafter MI-Nafīsī).

${ }^{18}$ See $J M, 3: 329-331$ for biographical notice on $\mathrm{Mu}$ 'īnuddīn.

${ }^{19}$ Maḥmūd Kutubī, Tārīkh-i Āl-i Muẓaffar, ed. 'Abd al-Husayn Navā'̄i. (Tehran: Mu'assasah-i Intishārāt-i Amīr Kabīr, 1364/1985-6). Browne’s facsimile of Mustawfī’s Tārīkh-i Guzīdah (TG-Browne) contains Kutubī’s continuation; $T G$-Navā' 1 does not. Mention should be made of another Timurid-era history, Jāmi 'al-Tavārīkh-i Hasan̄̄, composed in 855/1451-2 by another Yazdī, Tāj al-Dīn Hasan Yazdī, who served under Prince Iskandar and later Sulțān Muhammad, both as a military commander of ten men and a provincial administrator in Kirmān. While this work does provide abundant information about the author's native Yazd, the narrative centers on the participation of Kirmān's governors in larger imperial affairs: Tāj al-Dīn Hasan ibn Shihāb Yazdī, Jāmi ‘alTavārīkh-i Hasanī ed. Husayn Mudarrisī Ṭabāṭabā'ī and Īrāj Afshār (Karāchī: Dānishgāh-i Karāchī, 1987).

${ }^{20}$ See Stephan T. Kamola, "Rashīd al-Dīn and the making of history in Mongol Iran,” PhD Dissertation, University of Washington, 2013.
} 
were quite focused on this figure's relationship with their home city. For this reason, consideration of Rashīduddīn's special connection to Yazd and its elite families is necessary.

Ilkhanid-era sources demonstrate that Rashīduddīn had deep financial investment in Yazd. His own waqf-nāmah for his complex in Tabrīz, Rab '-i Rashīdī, shows that he had made endowments of extensive properties in Yazd, more than in any other region. ${ }^{21}$ But in addition to the vizier's well-documented material interests there, the Yazdī historians establish that Rashīduddīn cultivated personal relationships there too. They relate that in his early years, perhaps even before he converted to Islam from Judaism, Rashīduddīn had sojourned in Yazd in order to study medicine with one of the city's great notables from the Rażī family, Sharafuddīn 'Alī al-Ṭabīb. Later, in honor of his former teacher, he built a madrasah in Yazd close to the Atābeg's madrasah, called the Rashīdīyah. ${ }^{22}$ Rashīduddīn and his son, Ghiyāšuddīn, who also rose to his father's rank of grand vizier, forged marriage alliances with Yazdī sayyid families. As a consequence of these entanglements in Yazd, the Yazdī historians provided father and son with substantial biographical notices in their local histories, as honorary townsmen. ${ }^{23}$

The Mongols had long attracted men like Rashīduddīn to court who were polylingual, learned men from the notable families of provincial urban centers. However, by the late thirteenth and early fourteenth centuries, the İlkhāns increasingly involved themselves in the affairs of

\footnotetext{
${ }^{21}$ Fażlullāh Rashīduddīn Hamadān̄̄, Waqf-Nāmah-i Rab '-i Rashīd̄̄, ed. Mujtabá Mīnovī and Īraj Afshār (Tehran: Anjuman-i Āthār-i Millī , 1972), 61-132. Also see: Birgitt Hoffman, "In Pursuit of Memoria and Salvation: Rashīd al-Dīn and His Rab -i Rashīdī," in Politics, Patronage, and the Transmission of Knowledge in $13^{\text {th }}-15^{\text {th }}$ Century Tabriz, ed. Judith Pfeiffer (Leiden: Brill, 2014), 171-185, and her "The Gates of Piety and Charity: Rašīd alDīn Fadl Allāh as Founder of Pious Endowments," in L'Iran Face à la Domination Mongole, ed. Denise Aigle (Tehran: Institut Français de Recherche in Iran, 2007), 189-201. Also see Īraj Afshār, "Rashīduddīn va Yazd," İrānshināsī: Majallah-i Taḥqūqāt-i İrānī-i Dānishkadah-i Adabīyat va 'Ulüm-i Insān̄i-i Dānishgāh-i Tihrān, II/1, $1970,23-33$.

${ }^{22} T Y, 92-3 ;$ TJY, 134-5. A khānqāh, bazaar, and caravanserai were added later. The larger complex was not completed until $725 / 1325$.

${ }^{23}$ Some accounts claim that Ghāzān Khān appointed Rashīduddīn Yazd's governor: Shabānkārah'1̄, $M A, 214$. Kamola asserts that this is mentioned in Munshī Kirmānī’s history of the Qutlugh Khāns (Qarā Khitā' īs) of Kirmān, Simt al- 'ülā' li'l- hạ̣rat al- 'uliyā', ed. 'Abbās Iqbāl (Tehran: Asāțir, 1983). See discussion in Kamola, "Rashīd alDīn," 114-15,120. I have trouble verifying the reference in Iqbāl's edition.
} 
provincial cities and reached out to the elites based there. Urban notables, like Rashīduddīn, who had already attained positions at the imperial dīvān, functioned as intermediaries and brokered new ties between the Mongol elites and the intellectual and spiritual powerhouses that were rooted in towns across the realm. ${ }^{24}$ The economic and professional ties with Yazdīs that had helped Rashīduddīn and his son build their wealth, prestige, and political careers, also served this interest of their imperial masters, who sought to bring closer to them the leadership of these provincial cities, like Hamadān, Baghdad, or Yazd. As will become clear below, in the case of Yazd, Rashīduddīn and his sons' partnerships with local notables, and particularly with sayyids, became instrumental in the Mongols' move to undermine defiant local military households, which had long possessed political power in the region. These were the Atābegs, who had been local mainstays of the old Saljukid order, who had ruled locally with a great deal of autonomy. ${ }^{25}$ Rashīduddīn did not always support the sayyids in all towns across the realm, as he did in Yazd; there are counter examples. ${ }^{26}$ His decision to favour some sayyids over others must be understood in the context of his larger program of realpolitik, which hinged, in part, on an evolving rivalry between Sunnis and Twelver Shī $a h .{ }^{27}$ Nevertheless, overall, the administrators of the Mongol center increasingly built relationships directly with local sayyid families and inserted themselves into their local affairs. In this regard, as Judith Pfeiffer has shown, Ghāzān

\footnotetext{
${ }^{24}$ Jonathan Brack investigates how Rashīduddīn and a handful of cultural brokers from Jewish, Shī' ì , and Buddhist communities fashioned the Ilkhanid imperial project of sacred kingship in the midst of fierce dynastic politics and sectarianism by mediating a variety of Mongol and local cultural and religious concepts. See his "Mediating Sacred Kingship: Conversion and Sovereignty in Mongol Iran," PhD Dissertation, University of Michigan, 2016.

${ }^{25}$ The Atābegs of Yazd were descended from Ruknuddīn Sām ibn Langar, whom the Saljuks appointed to rule as Atābeg in Yazd on behalf of the daughters of the last Kākūyid ruler of Yazd.

${ }^{26}$ In one case, Rashīduddīn opposed a powerful, Shi ite sayyid, Tājuddīn Āvajī after he had had gained control of the shrine of one of the Jewish prophets, Zַ̄ al-Kifl, near al-Hillah. The episode appears in Qāshānī, TU, 130-132. Pfeiffer references these events in: Pfeiffer, "Confessional Ambiguity," 152-53. See also Brack, "Mediating Sacred Kingship," 272-3.

${ }^{27}$ This rivalry was palpable during the Ilkhanid period, even if it was to dissipate into so-called confessional ambiguity during the following century. This is one of the theses in Pfeiffer, "Confessional Ambiguity." Also see Brack's treatment of Sa 'd al-Dawlah's handling of the Shī'ah in Baghdad in his "Mediating Sacred Kingship," 108124.
} 
Khān instituted a policy of support for the sayyids. Yazd's sayyids, in particular, benefitted from this outreach.

Rashīduddīn and his son, Ghiyāsuddīn, were well positioned to broker a harmonious association between the center and Yazd's sayyid families and to increase the latters' local authority at the expense of the Atābegs. However, the Yazdī historians compressed what was in fact a rather complicated set of political and social transformations into a single, rather intriguing narrative of events concerning one of these sayyid families, the Âl-i Nizāam, to which the Ilkhanid viziers would establish close ties. The reference here is to the curious narrative that opened this study. Ruknuddīn Muhammad, who built his new madrasah beside the Atābegs' complex, hailed from this Nizām family. He and his son, Shamsuddīn Muhammad, are the main protagonists of this story. The Nizāan line constituted one of the illustrious Husaynī lineages of Yazd, that of the 'Urayżī sayyids, who traced their ancestry to a brother of Imām Mūsā al-Kāzịm, named 'Alī al'Urayżī bin Ja far al-Ṣādiq. ${ }^{28}$ 'Alī al- 'Urayżì's descendant, Abū Ja ' far Muhammad, later settled in Yazd and consequently plays a major role in all three histories of Yazd. ${ }^{29}$

Since the era of the family’s namesake, Nizāmuddīn, long before the events in question, the Nizāms had held the prestigious local posts of naqīb and $r a$ 'ìs in Yazd. By the turn of the fourteenth century, however, this situation would change under the leadership of Ruknuddīn and his son, Shamsuddīn. The locus of the old Nizām family domain had long been outside the city center, around the Niẓāmīyah Khānqāh (built by Niẓāmuddīn), to the south of the city walls. ${ }^{30}$

\footnotetext{
${ }^{28}$ The 'Urayżī lineage is treated in Ibn 'Inabah's fifteenth-century genealogical works on the Țālibids. See his 'Umdat al-Ṭālib fì Ansāb Āl Abī Ṭālib, ed. al-Sayyid Mahdī al-Rajā'ī (Qum: Maktabat Āyat Allāh al-'Uzṃá alMar'ashī al-Najafī, 2004), 296-301 and his al-Fuṣūl al-Fakhriyyah, ed. Jalāl al-Dīn Muhaddis Urmawī (Tehran: Shirkat-i Intishārāt-i 'Ilm va Farhang, 1984), 147-8. Ruknuddīn and Shamsuddīn are mentioned in the former work on $\mathrm{p} 300$ and in the latter on $\mathrm{p} 148$.

${ }^{29}$ The sources are nearly unanimous on this imāmzādah's descent: TY, 106; TJY, 151; JM, 3:520.

${ }^{30}$ Nizāmuddīn was buried there, and the site later became a popular burial ground for sayyids. Ja 'farī claims Ruknuddīn's father built a khānqāh on the premises along with his own mausoleum. See: TY, 118 and TJY, 172 . That site remained popular into Mufĩd's day. JM, 3:535. See: Afshār, Yādgār'hā-yi Yazd, 2:332-3.
} 
Ruknuddin chose to move to the center of city and establish a presence beside its entrenched institutions. There he built his new madrasah complex, the Ruknīyah. In the Yazdī historians' telling, the resulting conflict over the city's skyline between Ruknuddīn and the sitting Atābeg, called Yūsufshāh, triggered a disturbance and, ultimately, a political reconfiguration of the city.

\section{A City Disturbed: tales of a father and son}

In the Yazdi histories the contested erection of this new madrasah complex in the city center, which would not be completed until 725/1324, forms the core event in Ruknuddīn and Shamsuddīn's biographies. This story is unique to the Yazdī histories. The authors describe the site as a monumental one, which, in addition to the madrasah itself, featured two minarets, a pharmacy, a mosque, a library, an observatory with an astronomical water-clock, and eventually a mausoleum for the founder. ${ }^{31}$ The latter, like many tombs of the Imāms' descendants (imāmz $\bar{a} d a h s$ ) ultimately became sites of ritual visitation (ziyārat), where pilgrims would travel to offer supplications and to bind vows. This information about the complex's buildings is corroborated by Jāmi 'al-Khayrāt, the collection of endowment deeds for all the works of father and son. This new site was situated in the quarter that came to be known as Vaqt o Sā'at, directly beside the old Madrasah-i Mạ̣mūd Shāhī. The latter site had been named for the building’s founder, Atābeg Maḥmūd Shāh (r. late seventh/thirteenth century), one of the early, benevolent Atābegs, whose father, Quṭbuddīn, had constructed the city-center in Yazd, and whose mausoleum was nearby. ${ }^{32}$ The succeeding Atābegs had their bodies entombed in the madrasahs that were built in close proximity to Quṭbuddīn's tomb; indeed, the area was a sacrosanct

\footnotetext{
${ }^{31}$ Descriptions of the Ruknīyah complex are found in: TY, 81-84; TJY, 123-5; JM, 3:654-6. Compare with analysis of Ruknīyah and Shamsīyah in Renata Holod-Tretiak, "The Monuments of Yazd, 1300-1450: Architecture, Patronage and Setting," (PhD Dissertation, Harvard University, 1973), 24-73; Robert Hillenbrand, Islamic Architecture: Form, Function, and Meaning (Edinburgh: Edinburgh University Press, 2000), 224, 226, 520.

${ }^{32} T Y, 24-26 ; T J Y, 69-71,125 ; J M, 1: 86-8$.
} 
necropolis for the Atābegs. Kātib explains that Atābeg Yūsufshāh had refurbished the Madrasah-i Maḥmūd Shāhī just before Ruknuddīn decided to build his own complex beside it. ${ }^{33}$ The remaining strands of a rather tangled story then spring out from this tension between the sayyid and local sovereign, a competition for mastery of the city's skyline and holy ground. Each of the three authors presents the account of this conflict that unfolds around the Rukniyah in relatively similar ways, save for a few key variations. Clearly, each successive account was penned with the previous ones at arm's reach.

The narrative proceeds as follows: When Atābeg Yūsufshāh learns of Ruknuddīn's decision to build in the city-center, he interprets the move as an affront to his own family's dignity and authority. The sayyid's choice to transfer the family's territory from outside the city walls into the center and to build a large madrasah complex and mausoleum beside those of the ruling house was an audacious move. Perhaps he had been emboldened by the recent erection of Rashīduddīn's Rashīdīyah complex nearby. Nevertheless, in all three texts, the outraged Atābeg Yūsufshāh immediately plots to discredit the sayyid and ruin him. Here we return to Mufĩd's eloquent prose that opened this article:

Untamed malice mounted the saddle of vengeance and charged the sayyid down. At once, from out of the arcane abode of the wheel of fortune, the juggler began to juggle and a strange affair came about. Thus, the decree of misfortune got hold of the sayyid. ${ }^{34}$

Desperate for some pretext to attack the sayyid, the Atābeg incriminates him in the murder of a wealthy Christian merchant who had recently been butchered in his home by a gang of thieves, an accusation the authors consider absurd. As Mufīd puts it, Yūsufshāh, "having planted the sapling of rancor for the sayyid in the field of his breast and having nourished it with

\footnotetext{
${ }^{33} T J Y, 125-6$.

34 "tawsan-kīnah dar zīr-zīn-i intiqām kashīdah dar pay-i sayyid mītākht. Nāgāh az nihān-khānah-i charkh

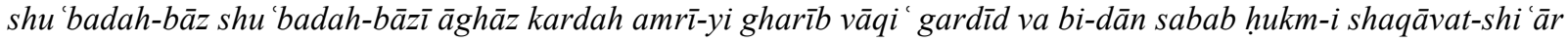
bar ān janāb dast yāft." JM, 3:543-44. Analogous passage in TJY, 125-6.
} 
the water of villainy and enviousness... implicated the sayyid in this heinous affair and caused the purity of the skirts of the sayyid's robe to be polluted with the stain of treachery." ${ }^{35}$ Kătib goes as far as to have the Atābeg accuse the sayyid of plotting the murder and robbery of the Christian in order to recoup the extravagant madrasah's construction costs. ${ }^{36}$ In the end, the preposterousness of the Atābeg's testimony proves inconsequential. After a sham trial Yūsufshāh has the sayyid publically tortured and tosses him into a dungeon outside the city. ${ }^{37}$

Not yet satisfied, the Atābeg trains his eye on the sayyid's son and successor, the fourteen-year-old, Shamsuddīn, but the boy hides himself at the home of a loyal friend. As Yūsufshāh redoubles his search, the narrative slips into a more hagiographical register, wherein another devotee of Ruknuddīn, Khvājah 'Alīshāh, encounters the Prophet Muhamamad in a dream. The Prophet directs the khvājah to Shamsuddīn's hideout and instructs him to smuggle the boy out of the city so that he can make his way to Ilkhanid court at Tabriz to seek intercession on the sayyids' behalf against the Atābeg's tyranny. 'Alīshāh follows the Prophet's instructions, and the young Shamsuddīn sets off through the desert. ${ }^{38}$

Along the way he arrives, perilously thirsty, at a ruin in the wilderness but finds only fetid water. He nearly expires, but is saved by a miraculous rain. Afterward, the young sayyid magically makes his way in just a few days to Ūjān-i Tabrīz, where the Ilkhanid pādishāh, Abū Sa ${ }^{c} \mathrm{i}$, was holding court. ${ }^{39}$ The scene changes abruptly, and we are taken into the bedchamber of the pādishāh's Grand Vizier, Ghiyāșuddīn, the son and successor of Rashīduddīn. There, the Prophet appears in the vizier's dream. He tells Ghiyāsuddīn about his blessed descendant, the exiled Shamsuddīn, calling him "my son" in Mufīd's version. He then explains where the boy is

\footnotetext{
${ }^{35} J M, 3: 544$. Comparable passages: $T Y, 84 ; T J Y, 126$.

${ }^{36} \mathrm{TJY}, 126$.

${ }^{37} T J Y, 126, J M, 3: 544$.

${ }^{38} T Y, 84 ; T J Y, 126-7 ; J M, 3: 545-6$.

${ }^{39}$ TY, 85; TJY, 127; JM, 3:549.
} 
staying and requests that he bring him before the sovereign to ask for assistance. The vizier wakes up, locates Shamsuddīn, and presents him to the Īlkhān, Abū Sa '̄ìd. The boy easily convinces the sovereign of Atābeg Yūsufshāh's villainy and of the innocence of his own father, and so $\mathrm{Abu}$ Sa ${ }^{1} \overline{1} \mathrm{~d}$ dispatches an emissary to Yazd to free Ruknuddīn. ${ }^{40}$ Before presenting this segment of the story in detail, however, the texts explain that a close relationship meanwhile develops between the Vizier Ghiyāsuddīn and Shamsuddīn. Moreover, Shamsuddīn receives a robe of honor from $\mathrm{Abu} \mathrm{Sa}$ ' $\overline{1}$, who appoints him the deputy of the vizier and supervisor of the realm's judges and endowments. ${ }^{41}$ Furthermore, the vizier gives Shamsuddīn his sister in marriage. $^{42}$

The narrative then returns to Yazd. The IIlkhān's envoy arrives and dispatches a band of men to free Ruknuddin from the dungeon. At this moment the reader encounters one final miracle. When the Îlkhān's soldiers peer into the chamber, they find Ruknuddīn protected by a venomous asp, neatly coiled upon the hem of his skirt. Recognizing these men as Ruknuddīn's liberators, the serpent vanishes, allowing them to escort the sayyid back to the city, where the populace welcomes him in jubilation. ${ }^{43}$

We are told that the envoy installs Ruknuddīn as the chief Qāżī of Yazd, and sets up a tribunal (majlis) within the Ruknīyah complex, where he brings those responsible for the injustice before the sayyid. Rather than exacting retribution, Ruknuddīn forgives all his former adversaries and returns the city to a state of peace. ${ }^{44}$ There is a kink in the narratives here: the texts say

\footnotetext{
${ }^{40} T Y, 85-86 ; T J Y, 127-8 ; J M, 3: 549-51$.

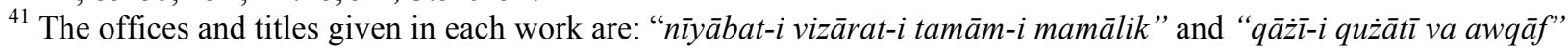
(TY, 85); "nīyābat-i 'āmmah-i mamālik va qażā va șadārat" (TJY, 127-8); "șadārat-i mamālik va nīyābat-i 'āmmah va qażā-i kul-i vilāyat” (JM, 3:551-52).

${ }^{42}$ Mufīd erroneously writes here that Shamsuddīn married Ghiyāsuddīn's daughter. All sources agree that he married Ghiyāsuddīn's sister (Rashīduddīn's daughter). Elsewhere, Mufīd correctly identifies her; JM, 3:549-52; TY, 88-9; TJY, 131.

${ }^{43} T Y, 85-6 ; T J Y, 128 ; J M, 3: 553$.

${ }^{44} T Y, 86 ; T J Y, 128 ; J M, 3: 554$.
} 
nothing of Atābeg Yūsufshāh's fate. As the instigator of the tyranny, one would expect either his arrest or at least some mention of his name among those oppressors whom the sayyid granted clemency. He simply disappears from the narrative.

The biography concludes with the sayyid's death and burial at the madrasah but first describes a number of his other major construction projects throughout the city and the realm at large, which he builds after making Hajj. The focus, though, is on a new subterranean canal (qanāt), which Ruknuddīn digs to conduct mountain water to the key religious centers of the city center and to fund the endowments for his new madrasah and other institutions. ${ }^{45}$ It originates in Farāshāh, a village on the south side of the city near Taft. Farāshāh held special significance for the sayyids because it featured a qadamgāh marking a spot where the Eighth Imām, 'Alī al-Riżā, stood on his way through Yazd to Khurāsān. This canal, which he names Āb-i Vaqfābād (also called Qanāt-i Taft), enters Yazd from the south, stops in the congregational mosque, and then passes into the Ruknīyah complex, before ultimately leaving the city walls, and terminating at the house of his teacher, Muḥammad Ya 'qūb, to the northwest. Ja ' farī and Kātib specify that along the way the sayyid also channels this stream to the Rashīdiyah. ${ }^{46}$

Immediately thereafter, the histories describe the building projects of Ruknuddīn's son, Shamsuddīn, now brother in-law of the vizier Ghiyāsuddīn, and a high-ranking official of the Ilkhanid court. The crowning edifice, completed in 727/1326-7, is the Shamsīyah Madrasah, where he would ultimately be buried in $733 / 1332-33 .{ }^{47}$ In $724 / 1325$ Shamsuddīn also begins a new congregational mosque, which he integrates into the old one, without completely replacing the original structure. ${ }^{48}$ Clearly, at his point the Niẓāms could now confidently associate

\footnotetext{
${ }^{45} J K, 174,199$.

${ }^{46} T Y, 86-7 ; T J Y, 128-9 ;$ JM, 3:556; JK, 31-2.

${ }^{47}$ Shamsuddīn's wife transported his body from Tabrīz to Yazd for interment. TY, 88-89; TJY, 131; JM, 3:559.

${ }^{48}$ Holod-Tretiak, "Monuments of Yazd," 81-82, 84.
} 
themselves with the most important religious monument of the city, without fearing reprisal from the Atābegs. Mufīd also stresses that Shamsuddīn builds a Dār al-Siyādah, the first such hospice for sayyids in Yazd. Judith Pfeiffer has demonstrated that Ghāzān Khān advanced the building of Dār al-Siyādahs in major cities of the realm as part of his larger policy of promoting the sayyids above other classes of local religious and military elites, as the preeminent Muslim authorities in the empire. ${ }^{49}$ Indeed, the Yazdī sources make clear that Shamsuddīn produced the plan for the complex while serving at the Ilkhanid court, and sent agents to Yazd to realize his plans. ${ }^{50}$ This suggests that Shamsuddīn's construction program was executed in coordination with the Ilkhanid policy toward sayyids that Pfeiffer describes. In the end, the later two Yazdī accounts attest that the mausoleums of the Ruknīyah and Shamsīyah madrasah complexes both served as places of ziyārat, even to Mufìd's day, in the seventeenth century. ${ }^{51}$

Meanwhile, we also discover that Ruknuddīn marries one of his_daughters to Żiyā'uddīn Husayn Rażī, the son of Sharafuddīn 'Alī al-Rażī, the man who had been Rashīduddīn's teacher of medicine in Yazd. Shamsuddīn's biography closes with mention of the marriage of his daughter, 'Iṣmatuddīn Arslān Khātūn, (Rashīduddīn's granddaughter) to yet another illustrious Yazdī sayyid, Mu'īnuddīn Ashraf, who hailed from a different branch of the 'Urayżì sayyid lineage. ${ }^{52}$ Thus, by the end of the notices on this father and son, the Yazdi authors neatly tie these various sayyid and local patrician family lines to one another. In doing so, they also link these families to great the vazīin family of the Ilkhanid capital. Moreover, they present this new

\footnotetext{
${ }^{49}$ Pfeiffer, "Confessional Ambiguity," 143-150. Pfeiffer locates Ghāzān's order for the building of Dār al-Siyādahs in Qāshān̄̄'s TU (p. 93). These were to be constructed in Tabrīz, Iṣfahān, Shīrāz, Baghdād, Kirmān, Kāshān, Sivas, Kūfah, and Yazd. Also see Holod-Tretiak, "Monuments of Yazd," 55, 150.

${ }^{50} T Y, 88 ; T J Y, 129-30 ; J M, 3: 558-9$.

${ }^{51}$ For ritual visitation to Ruknuddīn's tomb: $J M, 3: 655$, to Shamsuddīn's tomb: TJY, 131; JM, 3:559, 655-56. Ja farī doesn't mention visitation.

${ }^{52} T Y, 89 ; T J Y, 131 ; J M, 3: 559-60$. The daughter's name is not given in the Yazdī histories but is mentioned in $J K$, 70. The Yazdī historians explicitly put Mu'īnuddīn Ashraf in the 'Urayżì lineage in the above-cited passages, without specifying his particular line of descent.
} 
patronage network as being materialized in the new urban landscape of the city - a set of madrasah complexes, Husayn̄̄ shrines, and new congregational mosque, connected by a freshlydug canal, which provides both water and revenue for their endowments.

There is good evidence corroborating the Yazdī authors' claims that Shamsuddīn did in fact become an extremely powerful and wealthy figure in the Ilkhanid administration, as Jean Aubin has demonstrated in his article on the Āl-i Nizāam. ${ }^{53}$ A passage at the end of Mustawfī’s $T G$ singles out Shamsuddīn Muhammad, praising him in sublime terms for his good works and effective management of the pensions of sayyids, qāżīs and the like. Mustawfì does not specify the title of the sayyid's office, but the activities he describes are consistent with those of the post that would later be called șadr. ${ }^{54}$

In an article on the family's endowments and benefactions, Akio Iwatake offers further evidence of Shamsuddīn's exalted status. He asserts that Shamsuddīn must have accompanied the

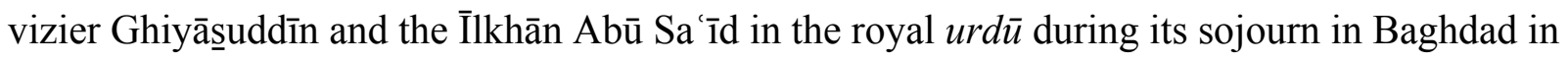
the winter of 733/1332-3, an episode that is recorded in Aharī's Tārīkh-i Shaykh Uvays. ${ }^{55}$ That text does not mention Shamsuddīn during that episode, but Iwatake concludes that just before he died in Tabrīz, Shamsuddīn must have been in attendance in Baghdad because it was at that time that the Grand Qāżì of the city, Muḥammad ibn 'Umar ibn Muḥammad al-Fażlī was the first to sign the compilation of the deeds for the family's awqāf, Jāmi 'al-Khayrāt, verifying its

\footnotetext{
${ }^{53}$ Jean Aubin, "Le Patronage Culturel en Iran Sous les Īlkhāns Une Grande Famille De Yazd," Le monde iranien et l'Islam 3, 1965.

${ }^{54} T G$-Navā'̀̄, 620-1.

${ }^{55}$ Akio Iwatake, "The Waqfs of the Nizām Family in Fourteenth Century Yazd,” The Shirin 72.3, 1989, 16. I am grateful to Mimi Hanaoka for providing an English translation of this article, which is in Japanese. See Abū Bakr alQuṭīi Aharī, Tārīkh-i Shaykh Uwais (History of Shaykh Uwais) an important source for the history of Adharbaijān in the fourteenth century (The Hague: Excelsior, 1954), 156-157.
} 
authenticity. ${ }^{56}$ While this evidence does not explicitly confirm the title of Shamsuddīn's office, it implies that indeed Shamsuddīn had found his way into the highest echelons of the Ilkhanid society and had attained an exalted rank.

As Aubin noted, even stronger evidence of Shamsuddīn's high station can be found in Muhạmmad ibn Hindū-Shāh Nakhchivān̄̄'s administrative manual, Dastūr al-Kātib fì Ta ẏ̄n alMarātib. Muḥammad Nakhchivānī served in the dīvān-i inshāa and was a confidant and protégé of the vizier, Ghiyāșuddīn. In fact it was Ghiyāṣuddīn who had suggested Nakhchivānī compose the Dastūr. ${ }^{57}$ In that work, the author explicitly names Shamsuddīn as Ghiyāsuddīn's deputy ( $n \bar{a} ' i b)$, and specifies that in that office, he increased the pensions of the sayyids, qāżīs, 'ulamā' and the like. ${ }^{58}$ Nakhchivān̄̄’s eyewitness testimony leaves little doubt that Shamsuddīn had indeed attained an extraordinarily high post in the imperial dīvān. Moreover, the Niẓāms’ endowment deeds attest that both father and son had acquired considerable capital and were able to build extensively in Yazd and other parts of the realm. ${ }^{59}$ Taken together, these are clear signs that these sayyids possessed the means to cast their shadow over the buildings of the local Atābegs and far beyond Yazd's walls, as the Yazdī historians assert.

The high status of Yazd's 'Urayżī sayyids as imperial actors and local benefactors continued into the Muzaffarid period, where there was a close relationship between that ruling house and the line of Mu 'īnuddīn Ashraf, who had married Shamsuddīn's daughter, as was

\footnotetext{
${ }^{56} J K, 202-203$.

${ }^{57}$ The Dastūr al-Kätib was completed in the mid-eighth/fourteenth century, years after Ghiyās al-Dīn's death, and was dedicated, in the end, to the Jalāyarid Sulțān Uvays (d. 776/1374).

${ }^{58}$ Muḥammad ibn Hindū-Shāh Nakhchivān̄i, Dastūr al-Kātib fì Ta'yīn al-Marātib, ed. 'Abdulkarīm 'Alīzādah, 2 vols. (Moscow: Nawka, 1964-76), 1:301. The role and duties of the office of the deputy of the vizier (nīyābat-i vizārat) are described in full (2:122-5). Aubin was the first to comment on this passage in his "Une Grande Famille De Yazd," 113.

${ }^{59}$ In Amīn Aḥmad Rāzī’s entry on the Ruknīyah and Shamsīyah complexes in his Safavid-era Haft Iqlīm (completed 1002/1594) the author asserts that every caravanserai between Yazd and Tabrīz was the work of this pair of sayyids. Amīn Aḥmad Rāzī, Haft Iqlīm, ed. Javād Fāżil (Tehran: Kitābfurūshī-yi 'Alī Akbar 'Ilmī va Kitābfurūshi-yi adabīyah, 1960), 1:147-8. Rāzī also specifies that the father and son ordered the founding of four hundred and fortyfour edifices on a single Wednesday.
} 
mentioned above. Like the Nizāam clan, the Ashrafìs constructed their own madrasah-shrine complex in the city center, the Husaynīyah, and they built and endowed many others. More importantly, Mu '̄inuddīn's son, Ruknuddīn Shāh Ḥasan became the Grand Vizier of the Muẓaffarid sovereign, Shāh Shujā' ${ }^{60}$

The fact that the Yazdī sayyids rose to prominence during the rule of the İlkhāns is certain, but the Yazdī historians' choice to situate the narrative of their emergence on the imperial scene in the context of a local conflict with the Atābegs reveals more about the authors' objectives. The lesson that this story about Ruknuddīn and his madrasah was meant to convey in those Yazdī texts seems fairly straightforward: Yazd's prominence originated with blessed sayyids, whose, knowledge, justice, and piety allowed them to develop their home-city in ways that the Atābeg rulers could not, and, through the miraculous intercession of the Prophet himself, the sayyids managed to solidify close relationships with members of the imperial court. The story is highly reminiscent of common saints' tales, and the Yazdī authors were likely drawing on an oral storytelling tradition for their accounts that was circulating around the Rukniyah complex and other sayyids' shrines. By the late fourteenth century, the tombs had already become the focus of ziyārat, and such stories would have furnished the kind of sacred mythology requisite for such shrines. Set to paper for the first time over a century after the events in question, the Yazdīs' integration of this hagiographical story about the Nizāms into a wider narrative about Ilkhanid politics constitutes an obvious compression of more complicated social and political transformations that had occurred at Yazd and at court.

\footnotetext{
${ }^{60}$ The Yazdī sources do not elaborate on Ruknuddīn Hasan's vizierate, which is discussed in Kutubī, Tārīkh-i Āl-i Muẓaffar, 98 and Ghiyāṣuddīn Khvāndamīr, Tārīkh-i Habīb al-Siyar, ed. Jalāl al-Dīn Humā'̄̄ (Tehran: KitābKhānah-i Khayyām, 1333/1954), 3:304-5. He was executed for corruption and clumsy scheming. Even his father, $\mathrm{Mu}$ 'īnuddīn, boycotted the funeral of his disgraced son.
} 


\section{The Last Atābeg: tales of another father and son}

There are certain hiccups in the story that give clues about what the Yazdī histories obscure and why. The first indication that the Yazdī narrative might be concealing some complexity has already been mentioned: the fate of Atābeg Yūsufshāh, the ringleader of the conspiracy, remains unexplained. The last Atābeg quietly drops out at the conclusion of the story. To make matters more complicated, it turns out that there are actually two contradictory stories about Yūsufshāh in all three of the Yazdī histories. The first narrative, which revolves around the Ruknīyah Madrasah, has just been recounted. Let us refer to this first narrative as "Narrative A." It appears in the course of the authors' notices on the two sayyids and their madrasahs. But in a separate, earlier section of these works, the Yazdi histories each rehearse a full account of the Atābegs' rule in chronological fashion, where they detail their eventual collapse during Yūsufshāh's reign. ${ }^{61}$ Let us call this "Narrative B." These chronological accounts in Narrative B relate a completely different story about Atābeg Yūsufshāh that does not square well with the one that these same authors tell about the Ruknīyah madrasah. In fact, Ruknuddīn and Shamsuddīn don't even come up in this other Yūsufshāh story. It turns out that this second account, Narrative B, actually corresponds fairly well with the account of Yūsufshāh's fall in Mu 'īnuddīn Yazdī’s history of the Muzaffarids as well as with the fragmentary accounts of the Atābegs that appear in the earlier chronicles of Rashīduddīn, Vașșāf, and Shabānkārah' '̄o albeit with some variations. In any case, there is no trace of the Ruknīyah story or even of Ruknuddīn in any of these earlier works either. ${ }^{62}$ The Yazdī historians appear to have borrowed heavily from their predecessors for

\footnotetext{
${ }^{61} T Y, 23-29 ; T J Y, 66-79 ; J M, 1: 83-93$. Yūsufshāh sections are: TY, 26-29; TJY, 74-79; JM 1:90-93.

${ }^{62}$ Vașșāf, TV, 253; Shabānkārah' '̄ $, M A, 212-14$. Rashīduddīn only mentions Yūsufshāh obliquely. (See below). Kutubī/Mustawfî’s account of Atābeg Yūsufshāh falls in the midst of his discussion of Sharafuddīn Muzaffar's rise to power at the expense of the Atābegs of Yazd. (In Mustawfī, TG-Browne, 616-619; in Kutubī, TAM, 30-31.)
} 
their chronological section on the Atābegs, but it is curious that they did not bother to reconcile that narrative with the other one about the Rukniyah fiasco (Narrative A).

When we examine the Yazdīs' Narrative B together with some Ilkhanid- and Muzaffaridera sources, we discover in all of them, first of all, that the chronology of the Atābegs' dynastic succession is in disarray. No two works agree on the succession of rulers, the genealogy of the family, or the key events of their rule. The discrepancies are not only between the various works, but there are internal inconsistencies within them. ${ }^{63}$ Nevertheless, when we compare the varied accounts of Atābeg Yūsufshāh's reign itself, we can discern essentially the same basic narrative schema in the Yazdī sources (Narrative B), and some of the universal Ilkhanid-era sources: These all begin with Atābeg Yūsufshāh's failure to send tribute to the Ilkhanid court. Some sources present the Atābeg as arrogantly challenging Mongol authority and embezzling local funds for his own enrichment; others claim that he was a benevolent and capable ruler, but had acted rashly, and had been goaded into rebellion by cunning rivals at court who were jealous of the Mongols' trust in him. ${ }^{64}$ Regardless of his original intentions, in all accounts Yūsufshāh makes a grievous error when a Mongol amīr, called Yesüder, arrives in Yazd to force the payment of tribute. The Atābeg has Yesüder murdered while asleep in his camp and has his wives and children seized. When this news reaches the Ilkhanid court, the governor of Ișfahān, Amīr Muhammad Īdājī, receives an order to attack Yazd. Seeing the approach of İdājī’s overwhelming force, Yūsufshāh flees for Sīstān with his family, together with the captured harem

\footnotetext{
${ }^{63}$ Full consideration in Derek Mancini-Lander, "Memory on the Boundaries of Empire: Narrating Place in the Early Modern Local Historiography of Yazd," (PhD Dissertation, University of Michigan, 2012), 329-367.

${ }^{64}$ In Mufĩd's rendition, the Atābeg is haughty and greedy (JM, 1:90-1); Ja farī blames scheming Mongol commanders $(T Y, 26)$. Kātib inculpates both the Atābeg and the Mongols. (TJY, 74-5.) Shabānkārah' '1’s account resembles Kātib's, wherein the Atābeg chooses to withhold tribute to Ghāzān out of pride; however, rivals use this as a pretext to convince the shāh that he had rebelled. $(M A, 2: 212)$. Vașșāf blames the Atābeg for deliberately fomenting revolts, although he narrates the story in the context of a larger rebellion of Afrāsiyāb of Lur (Vașșāf, $T V$, 253). Rashīduddīn does not relate the whole story of the Atābeg's fall, but recounts Yesüder's murder in Yazd during Arghūn's reign (see below): Rashīduddīn, JT, 2:820.
} 
of Yesüder. Yūsufshāh's fate varies in the sources: In Mu 'īnuddīn Yazdī’s, Kutubī’s, and Ja farī's accounts, the story simply ends with his exile in Sīstān (or Kirmān) ${ }^{65}$ Kātib has the ascendant figure of Sharafuddīn Muzaffar, the progenitor of the Muzaffarid dynasty, hunt him down and kill him. ${ }^{66}$ Nonetheless, the Yazdī sources agree that in the end, Amīr Muhammad Īdājī appoints one of his lieutenants, a man called Bulghadar, as darügah over Yazd, in the name of the İlkhāns. ${ }^{67}$ Thus he brings an end to Atābegid rule. Mufīd sums up the affair with characteristic eloquence, saying: "Through foolishness and haughtiness (binādān̄̄ va gardan$k i s h \bar{\imath})$, the two-hundred-year-old sultanate of the Atābegs was left open to an outsider (bīgānah). ${ }^{, 68}$

A related and glaring inconsistency that demands our attention is that all the sources, including the Yazdī ones, set these events during the reigns of Arghūn (683-690/1284-1291) or Ghāzān (694-703/1295-1304). Now, we should recall that Narrative A, about Atābeg Yūsufshāh and his tyrannical treatment of Ruknuddīn was set during Abū Sa '̄id's reign (716-736/13161335), a good two decades later. This means that the Yazdī histories contain two completely different stories about Yūsufshāh and about the end of the Atābeg dynasty, set decades apart.

An explanation can be found in the Yazd-centered Muzaffarid dynastic histories composed by Mu 'īnuddīn Yazdī and Mạ̣mūd Kutubī. As has already been mentioned, both provide only the B-version of the Yūsufshāh narrative, which is set during Arghūn's reign, and which says nothing about Ruknuddīn or his son. Mu'īnuddīn make a curious statement a few

\footnotetext{
${ }^{65} M I$-manuscripts: British Library Add 7632, fol 15a-b; MI-Nafīsī, 36; TAM, 31; TY, $27,95$.

${ }^{66} T J Y, 79$. Hāfiz Abrū 's fifteenth-century work relates that Yūsufshāh was assassinated by the Mongol envoys. He also states that this event coincided with the death of Arghūn. Hāiziz Abrū, Jughrāfiyāa-yi Hāafiz-i Abrū, ed. Șādiq Sajjād (Tehran, 1977), 2:198. Ghāzān pardons Yūsufshāh in Shabānkārah' '̄, $M A, 2: 213$. In Vașșāf, the affair takes place earlier, during Arghūn's reign, and then, later, Gaykhatu reinstates him as governor of Yazd. Vașșāf explains: "Although Atābeg Yūsufshāh of Yazd had also walked that same path of revolt, hostility, murder, plunder of the Mongols and Muslims, and squander of the properties of the state, he was granted special mercy and grace, and named governor of Yazd." Vașșāf, TV, 267.

${ }^{67} T Y, 28 ; T J Y, 77 ; J M, 1: 92 . \mathrm{Mu}$ 'innuddīn does not mention this appointment.

${ }^{68} J M, 1: 92$.
} 
folios after his treatment of Yūsufshāh's ousting, where he mentions that in the year 707/1307-8, during Ghāzān's reign, Sharafuddīn Muẓaffar went to Yazd but found such bickering (na 'ābīn̄, literally "crowing") and jealous wrangling (tậassud) going on among the notables that the place was overcome with a general malaise (malālatī); he became so fed up (sa'āmatì dāsht) that he simply left for Shīrāz. ${ }^{69}$ One wonders whether these squabbles might have involved Ruknuddīn and his son. The timing is too late for Yūsufshāh, who has just been ousted, according to the author, and it is too early to correspond with the conflict between the Atābegs and sayyids recounted in Narrative A of the later local histories, which was set during Abū Sa '̄id's reign. Was $\mathrm{Mu}$ 'innuddīn registering the beginning of a disturbance that eventually climaxed in the Rukniyah affair? If so, which Atābeg would have remained in Yazd to push back against these new powerbrokers?

A possible answer appears a few folios later. In the course of narrating the early career of Mubārizuddīn, Sharafuddīn Muẓaffar's son, Mu 'īnuddīn and Kutubī both relate a curious affair in Yazd that occurred at the start of Abū Sa '̄id's reign and that is not mentioned in any of the other Yazdī sources. Mu 'īnuddīn's and Kutubī’s accounts differ on many points but agree on the fact that Yūsufshāh was not actually the last Atābeg of Yazd after all. They explain that one more Atābeg, called Hậjjī Shāh, the son of Yūsufshāh, was entrusted to oversee Yazd on behalf of the Îlkhāns some time after the ousting of Yūsufshāh during Arghūn's reign. ${ }^{70}$

\footnotetext{
${ }^{69}$ MI-manuscripts: British Library Add 7632, fol 17a-17b; Fatih 4227, fol 11b; MI-Nafīsī, 39.

${ }^{70}$ MI-Manuscripts: British Library Add 7632, fol 23a; British Library Add 19807, fol 26b; Fatih 4227, fol 15b; $M I$ Nafīsī, 53. Mu 'īnuddīn's complicates things because in all the manuscripts the author gives Hājjī Shāh's father's name as Atābeg Sa d, not Atābeg Yūsufshāh. Earlier in the text, where he provides an account of the father, the manuscripts vary: In British Library Add 7632, he is called "Atābeg Sa d Quṭbuddīn Yūsufshāh" (fol 14a). In Fatih 4227, while he is called "Atābeg Sa 'd" on fol 15b, the name is written as "Atābeg Sa 'īd Quṭbuddīn Yūsufshāh ibn 'Alā' al-Dawlah" on fol. 9b but "Atābeg Quṭbuddīn Yūsufshāh" on fol. 10a. Moreover, Yūsufshāh's father's name is written as "Atābeg Sa 'd 'Alā' al-Dawlah" in British Library Add 7632, fol 13a, but "Atābeg Sa 'īd 'Alā' al-Dawlah" in Fatih 4227, fol 9a. Thus, Sa 'd or Sa'̄̄d appears to have been the given name of both father and son; Yūsufshāh or Quṭbuddīn Yūsufshāh would have been his cognomen. Another possible explanation is that Mu īnuddīn (or copyists) meant the title to be read "atābeg-i sa' $\bar{l} d$ or sa'd." This would mean that sa' $\mathrm{d} / \mathrm{sa}$ ' $\overline{\mathrm{i}} \mathrm{d}$ was not a personal name but an
} 
Mu 'īnuddīn makes it clear that Ḥājjī Shāh was a bloodthirsty man who had forged a close friendship with the equally vicious Injuid Amīr of Fārs, Kay Khusrav, the son of Mạ̣mūd Shāh Injū. ${ }^{71}$ He narrates a curious but familiar tale: While Amīr Kay Khusrav is in Maybūd scheming to acquire one of the prize horses in the stable of Maybūd's Muzaffarid governor, Mubārizuddīn, Atābeg Hājjjī Shāh meanwhile has a dispute over a handsome boy who is an attendant of Amīr Kay Khusrav's deputy $(n \bar{a} ' i b)$ in Yazd. A fight breaks out, and the $n \bar{a}$ ' $i b$ ends up dead. ${ }^{72}$ Learning of his deputy's slaying, Kay Khusrav marches together with Mubārizuddīn to Yazd.

After a battle Ḥàjjī Shāh flees. Mu '̄inuddīn closes the account saying:

That family, long established in kingship since days of old, disappeared because of an instance of injudiciousness ( $b \bar{l}$-khiradag $\vec{\imath}$ ). That house, long accustomed to good fortune ( $m a$ 'had-i kāmkāà ), was ruined over this trifle (bidīn juzvī kharāb gasht). ${ }^{73}$

Kutubī makes an important modification to the text that reflects a Timurid-era perspective on the imperial center's reach into local affairs, one that recalls the other sources' treatment of Atābeg Yūsufshāh's situation, earlier. He scales up Mu '̄nuddīn's account from a largely local affair into an imperial issue: In his version, Amīr Kay Khusrav conspires with Mubārizuddīn to send a report to the Ilkhanid ruler, Abū Sa'̄id, to the effect that Hāājī Shāh's murder of the $n \bar{a}$ 'ib had been a deliberate act of sedition, wherein he had specifically targeted the Amīr's deputy because he was in the service of the Īlkhāns. The Pādishāh then orders Amīr Kay Khusrav and

adjective describing "Atābeg," meaning "The Prosperous Atābeg." This is supported by the fact that in some manuscripts the author refers to the Ilkhanid Pādishāh as "Sulțān-i sa '̄id Ghāzān Maḥmūd." (BL Add 7632, fol 16a). The theory that Yūsufshāh was a cognomen and not a personal name is partly corroborated in the chapter on the Atābegs of Yazd in Shabānkārah' '̀'s $M A$, where the author gives all the Atābegs of Yazd the title "Yūsufshāh." (Shabānkārah' '̄ $, M A, 212-214$.). Kutubī, glosses over all of this, simply explaining that Hāājī Shāh's father was "Atābeg Yūsufshāh" (Kutubī, TAM, 35).

${ }^{71}$ MI-Manuscripts: British Library Add 7632, fol 23a; British Library Add 19807, fol 29b; MI-Nafīsī, 53

${ }^{72}$ MI-Manuscripts: British Library Add 7632, fol 24a; British Library Add 19807, fol 27b-28a; Fatih 4227, fol 16a; $M I$-Nafīsī, 55.

${ }^{73}$ MI-Manuscripts: British Library Add 7632, fol 25a; British Library Add 19807, fol 29b; Fatih, fol 16b; MI-Nafīsī, 58. Compare with TAM, 35-36. 
Mubārizuddīn to exact revenge. ${ }^{74}$ In the end, the last Atābeg flees. Neither Mu īnuddīn nor Kutubī’s works say where Ḥājjī Shāh fled to, but one might guess that he made for Sīstān, as his father had done, to take refuge with the renegade Nikūdarīs. ${ }^{75}$ In any case, Mu 'īnuddīn's and Kutubī's works demonstrate that there were two humiliating finales to the Atābegs' rule, rehearsed in the stories of both father and son. And, in Kutubī's fifteenth-century reworking, the denouements of Yūsufshāh's and Ḥājjī Shāh’s reigns share remarkably similar schemas that reframe Yazd's local affairs in terms of imperial ones:

1. The Atābeg murders the IIlkhān's representative

2. The Atābeg's rivals portray the murder as an act of rebellion against the İlkhāns.

3. The İlkhān sends a force to punish the Atābeg.

4. The Atābeg flees Yazd, probably for Sīstān, and vanishes.

Although the last two Atābegs' stories might easily have been confused on account of their similarities, the later historians of Yazd certainly knew well the history of Mu ìnuddinn, their Yazdī predecessor; Mufīd even explicitly referenced him for material related to the Muzaffarid period, where Hạjjjī Shāh appears. ${ }^{76}$ It seems that the Yazdī historians deliberately allowed this pair, father and son, to collapse into a single, ill-fated figure. They purposely left the chronology of events muddy, chose elements from the stories about both Atābegs' inglorious demises, and linked them to some controversy surrounding the rise of the sayyids. The story about Yūsufshāh's ignoble fall at the hands of Ilkhanid forces, which was well known and widely circulated in the Ilkhanid-era histories, took place too early to fit with the Rukniyah narrative. But no matter, his son Hậjjī Shāh's equally inglorious downfall, which shared some key narrative elements, fit well with the chronology of the Ruknīyah affair; both took place during Abu Sa'īd's

\footnotetext{
${ }^{74} T A M, 35$.

${ }^{75}$ In both works, Mubārizuddīn's next order of business was to crush the Nikūdarīs of Sīstān, who shortly after Hājjī Shāh's ouster, road out against him, reaching as far as Bāfq before Mubārizuddīn's forces cuts them to pieces. It is not clear why the Sīstānīs risked this expedition, and it is tempting to think that the defeated Atābeg might have had something to do with it, but if this were so, one would imagine the authors would have jumped at the chance to mention it. Kutubī, Tārīkh-i Āl-i Muzaffar, 37.

${ }^{76} J M, 1: 143,3: 329-30$.
} 
reign. The actual identity of the story's villain was unimportant to the Rukniyah narrative, as was the historical accuracy of the details surrounding the dynasty's overthrow. The core message of the episode was the righteousness of the Âl-i Nizāam, the sanctity of their madrasah-tomb complex, and the inviolability of their alliance with powerful figures at the imperial court. Consequently, the presentation of the protagonists as both local saints and pillars of the imperial realm required that they were paired with a foil — a villain who was diabolical, tyrannous, disloyal to the ruling empire, and disdainful of the Prophet's progeny. The amalgamated figure of the overthrown Atābeg effectively executed that role and allowed the authors to transform his myopic rebelliousness in Narrative B into pure fiendishness in Narrative A.

\section{Sanctifying Sayyids and Scribes}

The fact that the Atābegs fell twice suggests that the assertion of more direct Mongol governance actually occurred over the course of a generation, not all at once at the hands of the Niẓāms. That complex history, in which Ruknuddīn's family played only a small part in a much larger tangle of evolving political relationships between powerful figures at the royal and provincial courts, did not constitute a useful enough narrative for the Yazdī historians. Moreover, the real story of the Nizām family's ascent to high bureaucratic posts, which involved calculated marriage alliances, the strategic construction of branded monumental complexes, and probably considerable political scheming, would not have yielded a compelling narrative either. The Yazdī historians were concerned with presenting Yazd's sayyids as saintly partners of both the Īlkhāns and Rashīduddīn's family against a mutual, purely evil foe, whose rise to prominence within the imperial system was attended by miracles and divine intercession. These historians were endeavoring to transform Yazd's sayyids from the pious, munificent, and savvy bureaucrats that 
they were, into true saints. Of course, the Nizāams had not attained their high level of wealth, power, and influence by political stratagem alone; their sacred lineage had already afforded them a degree of charismatic authority. But as the Yazdī historians wove the varied accounts they had inherited into seamless, timeless hagiography, they also transformed the type of sanctity these sayyids had possessed through lineage alone into a thaumaturgic variety of sanctity that was usually characteristic of Sufi saints. ${ }^{77}$

To be clear, the authors' consecration of the narrative was not intended to exaggerate the extent of the sayyids' power under the Īlkhāns. Instead, it had the effect of reconfiguring the kind of authority, not the degree of power these sayyids were supposed to have wielded. Presenting the sayyids as thaumaturges legitimized their ascendancy in charismatic rather than in political or strictly genealogical terms. This ambition to sanctify the sayyids' emergence upon the stage of imperial politics fits into a larger program of narrative re-emplottment through which the Yazdī historians sought to transform and redeploy the memory of the sayyids' power and authority during the Ilkhanid era into a sort of foundation myth that reflected contemporary concerns about the status of powerful notables in Yazd who could not necessarily claim sacred lineages. By exhibiting the origins of the Nizām family’s ties to empire in a saintly and charismatic register, the Yazdī authors' narratives perform the work of legitimating the political and religious authority of Yazd's current notable families, both sayyid and non-sayyid.

This shift toward representing Yazd's sayyids as saints in Yazd's historiography occurred during the Timurid dispensation, when neither the 'Urayżīs, nor any other sayyids from Yazd attained quite such a high bureaucratic office as had Shamsuddīn or the Ashrafìs. In fact, Yazdī sayyids would not ascend to such high official posts again until Yazd's Ni 'matullāhī sayyids, a

\footnotetext{
77 This parallels Aubin's argument about the sanctification of the narrative around Bam's sayyids in the Timurid period. "Deux sayyids de Bam," 103-105.
} 
Sufi family who hailed from a different Ḥusaynī lineage, intermarried with the Qarā Qūyunlūs and later, with the Safavids, becoming some of the most powerful actors in the early Safavid state. ${ }^{78}$ Nonetheless, during the Timurids' reign, notable Yazdīs who were descended from nonsayyid lineages but were trained in the environs of the 'Urayżīs' madrasah networks, were beginning to become prominent actors at the courts of royal princes, not necessarily in high bureaucratic posts, but in influential roles, as poets, astrologers, mathematicians, and especially historians. These occupations proved crucial to the Timurids' efforts to fashion programs of sacred, imperial, legitimacy for themselves.

The career of Sharafuddīn 'Alī Yazdī, the author of the massively important Timurid chronicle, Zafar-nāmah, and major benefactor in Yazd, is instructive. Sharafuddīn 'Alī was not a sayyid, though he was the great-great grandson of Ruknuddin through the marriage of that sayyid's daughter to a member of the Rażī clan of physicians, Żiyā'uddīn. ${ }^{79}$ Nonetheless, he had amassed enough capital and stature to build his own madrasah and khānqāh complex in central Yazd, the Sharafiyah, where he was buried after his death in 858/1454. Moreover, Sharafuddīn 'Alī had risen to a high station during Shāhrukh's reign, serving as a poet, historian, mathematician, and astrologer to various Timurid princes. Although he may not have attained the high office that his great-great-uncle, Sayyid Shamsuddīn Muhammad, had achieved, his influence at court as an esotericist and poet may have been greater. More importantly, it was his

\footnotetext{
${ }^{78}$ The founder of the Ni 'matullāhī order, Shāh Ni 'matullāh Valī, was not an 'Urayżī, but was descended from another of Ja far al-Ṣādiq's sons, Ismā' '̄l. The hagiographies of the Ni 'matullāhīs (by Kirmān̄̄ and Và'iẓ̂) provide varying lineages, but agree on Ismā' $\overline{1}$ l as the common ancestor. See Jean Aubin's published edition of these sources: Majmū 'ah dar Tarjumah-i Aḥvāl-i Shāh Ni 'matullāh Valī (Tehran: Qismat-i Irān-shināsī, Instintū-yi Īrān va Farānsah, 1956), 22, 275. Mufīd does not record Shāh Ni 'matullāh's pedigree; he provides only the founder's Sufi silsilah.

${ }^{79}$ İlker Evrim Binbaş demonstrates that the Rażī family was not of a sayyid lineage, 'Urayżī or otherwise. See his, Intellectual Networks in Timurid Iran: Sharafuddīn 'Alī Yazdī and the Islamicate Republic of Letters (Cambridge: Cambridge University Press, 2016), 30-32, especially note 14. The family is conspicuously absent from Ibn 'Inabah's notices on the descendants of 'Alī al- 'Urayżì. See his 'Umdat al-Ṭālib, 296-301; al-Fușūl al-Fakhriyyah, 147-148.
} 
historical work on the Timurids, articulated in the language of conjunction astrology and esoteric science that provided sovereigns and their administrators with an effective model for communicating sacred legitimacy that would persist for centuries, among successor dynasties. ${ }^{80}$

It is suggestive then, that it was during the Timurid period, when notable Yazdī experts without sayyid lineages, like Sharafuddīn 'Alī, were performing these functions at the imperial center, that Ja 'farī and Kātib chose to characterize Ruknuddīn and Shamsuddīn as saints and not just as key functionaries of the imperial administration. The histories of Yazd imply that Yazdī notables' constellation of expertise in the natural and esoteric sciences and literary arts, which afforded them access to the imperial dīvān, was the patrimony of their blessed benefactors, Ruknuddīn and his son. While the livelihoods of Yazd's viziers, mustawfīs, and literary men were linked in a concrete way to the economic welfare of local sayyids' madrasah-shrines, their prestige as pious men further depended on the degree to which they could demonstrate devotion to and affiliation with the holy descendants of the Prophet in the city. Without sacred lineages they realized this connection, in part, through acts of ritual devotion and patronage at shrines, but also through their adroit performances as accountants, historians, astrologers, and jurists. These occupations exploited fields of knowledge thought to be the Nizāms' bequest.

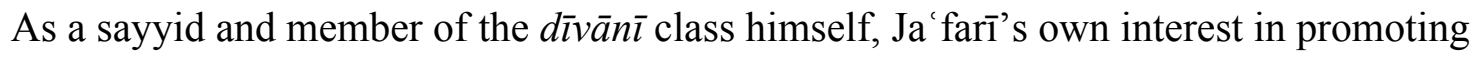
the role of Yazd's sayyids as saintly agents of imperial history and as the source of contemporary Yazd̄̄'s success is fairly obvious. And while he is sure to praise the building projects of nonsayyids, it is the 'Urayżīs' works that take center stage, as the potent relics of holy men. For him, the relatively recent success of Yazdīs on the imperial stage had emerged because of the rise of these sayyids above all local competitors in both political power and charismatic splendor. The work of Aḥmad Kātib who, like Sharafuddīn 'Alī, was not a sayyid is more nuanced. His

\footnotetext{
${ }^{80}$ This is a central argument in Moin's above-cited Millennial Sovereign.
} 
preoccupation with the 'Urayżīs and their participation in political affairs parallels his devoted coverage of the illustrious careers of Yazdīs without sayyid lineages too. Palpable is his determination to connect these figures to the local sayyids. For example, in his treatment of Sharafuddīn 'Alī’’s career, Kātib reminds readers of his ancestors' ties with the Nizāans and demonstrates his personal association with the contemporary Ni matullāhīs of Yazd. He is especially interested in illustrating how his astrological expertise, wisdom, and eloquent manners, which were the legacy of the Nizāams and their madrasah complexes, had influenced politics at the imperial court. ${ }^{81}$ Thus, Kātib portrays the sayyids' charismatic patrimony as having been apportioned among non-sayyid Yazdīs of later generations, like Sharafuddīn 'Alī, who continued to mobilize vestiges of the 'Urayżīs sacred knowledge in service of empire. There is a tacit implication that this patrimony is even shared among less illustrious servants of the empire, such as the author himself.

This sanctification of the non-sayyid notables and even rank and file members of the dīvān becomes more explicit two centuries later, in the work of Mufîd, who, like Kātib, was also not a sayyid. Even though he devotes a massive section of $J M$ to the prominence of Yazd's sādāt, he also elevates the status of non-sayyid imperial functionaries to a new level of sanctity. For example, in his lengthy notice on Sharafuddīn 'Alī, his description of the Sharafiyah madrasah complex and tomb, which does not appear in the earlier works, echoes his description of the Nizāams' monuments. ${ }^{82}$ And while Mufīd does not go as far as to imply that Sharafuddīn was a saint, the prominence of his monuments, presented alongside his influence at court as an esotericist, mathematician, and historian implies that his success was tinged with the sacredness of his sayyid predecessors.

\footnotetext{
${ }^{81}$ Mancini-Lander, "Memory," 269-77.

${ }^{82} J M, 3: 303$. The building was located beside Amīr Chāqmāq's mosque, but stood in ruins at the time of Mufĩd's writing.
} 
Furthermore, Mufĩd, who had personally witnessed a recent degradation of Yazd's madrasahs and the erosion of local sayyids' power at the Safavid court, considered the sayyids' charismatic patrimony available to Yazdīs of still less prestigious ranks and births. Indeed, Mufìd goes as far as to link even the pedestrian activities of the Yazdi bureaucrats of the empire to the sacred patrimony of Ruknuddīn. One last strange affair, which appears in Mufìd's eulogy for his own patron, the vizier Allāh Qulī Beg, provides a compelling illustration. ${ }^{83}$ He styles this vizier—a Qizilbāsh outsider who had lived in Yazd for forty years—as a pious patron of local sayyids, Sufis, and men of knowledge, and he presents the man's demise of a heart attack in 1079/1669 in the form of a quasi-hagiography. The disproportionately long anecdote begins when Allāh Qulī receives a letter from a friend who writes that after making ziyārat to the shrine of Mashhad, Imām 'Alī Riżā appeared in a dream. The Imām, who was busy circumambulating the throne of heaven, looked up, saying, "Soon Allāh Qulī Vazīr will be present in this blessed place." The devout vizier takes his friend's dream to be prescient and resigns himself to imminent death. He spends the next few days diligently wrapping up the affairs of his ministry, affixing his seal to important documents, and bidding farewell to all the meritorious people of the city. After three days, on Friday, 9 Zū al-Hijjah, the holy Day of 'Arafah, he dies, uttering the shahādatayn during Friday prayers among the notables and sayyids of the city.

Indeed, while the vizier was a pious man, he was no Sufi saint. After all, even the prescient dream with the Imām was a second-hand one. However, the particulars of the story leave no doubt that for Mufìd the vizier had some scent of holiness about him. Furthermore, while the account cleverly pairs proof of the vizier's piety with a display of his efficiency as an administrator, Mufìd takes this point a step further. He concludes the tribute by specifying that

\footnotetext{
${ }^{83}$ Mufĩd presents the order for Allāh Qulī’s appointment as vizier, dated Shavvāl 1078/March 1668 (JM, 3:209-210) together with the order for his assignment to other offices (3:221-2).
} 
the notables carried the vizier's body to the Rukniyah and buried him there. ${ }^{84}$ The ceremony at Ruknuddīn's grave effectively establishes that the author's benefactor, who served in the highest office of the imperial administration's local outpost, shared in the sayyids' charismatic patrimony. This was an inheritance that had originated with Ruknuddīn's divinely sanctioned triumph over a tyrannous governor who had been the enemy of the Prophet's progeny. That was a story that began with the erection of the very madrasah where this pious and punctilious beneficiary of the sayyids' legacy was ultimately buried, three centuries later. Mufĩd, who took over much of his deceased patron's responsibility, must have thought himself worthy of this trace of sacred inheritance as well. That sense of entitlement only increased his bitterness during his frustrating exile in India.

\section{Conclusion}

The Niẓāms' subversion of the Atābegs' time-honored skyline in Yazd coincided with a profound but gradual reorientation of the ritual and political life of Yazd. But the ongoing cultural and social effects of those transformations shaped the ways in which later historians of Yazd composed the history of their city and put it to use. By collapsing disparate narratives about the last Atābegs' insubordination against the Ilkhanid state together with local tales about the divinely sanctioned origins of the Nizāms' madrasahs, the Yazdī historians succeeded in legitimating the religious authority of the city's sayyids and in mythologizing their expert administration of the imperial order. The retooling of such tales for the eloquent prose-histories of the city had the effect of making the story instrumental for political ends. This appropriation allowed Yazd's historians to expand the sayyids' genealogical claims to be the legitimate agents of sacred empire into thaumaturgic ones that could be available to people from non-sayyid

${ }^{84} J M, 3: 233-236$. 
lineages. The history of the 'Urayżì sayyids' miraculous emergence as local and imperial power players thus served as a foundation story that could explain the origins of Yazdī sayyids' and non-sayyids' participation in imperial affairs more generally. Moreover, the divinely sanctioned triumph of the sayyids could then serve as both a model of and a model for the professional success of other local notables in imperial affairs, such as Sharafuddīn 'Alī Yazdī and Allāh Qulī Beg, as well as their respective eulogizers, Aḥmad Kātib and Mufĩd. Although non-sayyids could not claim sacred lineages, they could prove their right to participate in the administration of sacred kingship by making conspicuous displays of devotion to Yazd's sayyids and by emulating some of the charismatic qualities of saintliness that Ruknuddīn and his son had eventually come to embody. Indeed, Yazd's non-sayyids had become experts in the sorts of knowledge circulating around the sayyids' madrasah complexes, and, like the sayyids, they had even become eligible for receiving mantic knowledge from the Imāms in dreams. These credentials, combined with expertise in the arts of administration, made these figures uniquely suited to serve empires in search of religious legitimacy. Whether they held formal posts or simply received court patronage for their writings, Yazdī notables were instrumental in fashioning and administering programs of imperial sanctity, from the Timurid to Safavid eras. Nevertheless, these figures worked in increasingly competitive environments, where claims of association with sayyids and demonstrable ties to their shrines served as key means of securing access to the imperial center for notables in other regions as well.

Derek J. Mancini-Lander

SOAS, University of London 